\title{
Efektivitas Creative Problem Solving Disertai LKS Terhadap Hasil Belajar dan Motivasi Kelas VII SMPN
}

\author{
Aryanto, Laili Fitri Yeni, Reni Marlina
}

(C) 2020 JEMS (Jurnal Edukasi Matematika dan Sains)

This is an open access article under the CC-BY-SA license (https://creativecommons.org/licenses/bysa/4.0/) ISSN 2337-9049 (print), ISSN 2502-4671 (online)

\begin{abstract}
Abstrak:
Penelitian ini bertujuan untuk mengetahui efektivitas model Creative Problem Solving disertai LKS terhadap hasil belajar dan motivasi siswa pada materi Pencemaran Lingkungan kelas VII SMPN 2 Pontianak. Bentuk penelitian ini adalah eksperimen semu (Quasi Eksperimental Design) dengan rancangan nonequivalent control group design. Sampel penelitian terdiri dari dua kelas yaitu kelas VIID sebagai kelas eksperimen dan kelas VIIG sebagai kelas kontrol. Teknik pengambilan sampel adalah dengan cara Intact Group. Instrumen yang digunakan berupa tes pilihan ganda yang berjumlah 20 butir soal. Ratarata hasil belajar siswa yang diajar menggunakan model Creative Problem Solving disertai LKS sebesar 17,89 lebih tinggi bila dibandingkan dengan rata-rata hasil belajar siswa yang diajar menggunakan pembelajaran konvensional sebesar 16,94. Dari uji U Mann Whitney, diperoleh $Z_{\text {hitung }}>Z_{\text {tabel }}$ yaitu $5,33>1,96$, artinya terdapat perbedaan yang signifikan antara hasil belajar siswa yang diajarkan menggunakan model Creative Problem Solving disertai LKS dan pembelajaran konvensional. Nilai effect size yang diperoleh sebesar 0,65 termasuk dalam kategori sedang dan memberikan kontribusi sebesar $24,22 \%$. Hasil motivasi belajar kelas eksperimen yaitu $85,6 \%$ tergolong sangat kuat dan kelas kontrol yaitu 79,5\% tergolong kuat.
\end{abstract}

Kata Kunci: Model Creative Problem Solving; Disertai LKS, Pencemaran Lingkungan; Hasil Belajar; Motivasi Belajar

\begin{abstract}
:
This study aims to determine the effectiveness of the Creative Problem Solving learning model with student worksheets on student learning outcomes and motivation on Environmental Pollution material. This is a quasi-experimental research with a nonequivalent control group design on the class VII students of SMPN 2 Pontianak. The research sample consisted of two classes, chosen by using an Intact Group sampling technique, namely the VII D class as an experimental class and the VII G class as a control class. The instrument used was multiple-choice tests comprising 20 items. The average student learning outcomes taught using the selected model accompanied by student worksheets is 17.89 higher when compared to the average result of students instructed using conventional learning by 16.94 . In the Mann Whitney $U$ test, obtained $Z_{\text {count }}>Z_{\text {table }}$ by $5.33>1.96$, which means that there is a significant difference between student learning outcomes taught using the applied learning model accompanied by student worksheets and the conventional model. The effect size value obtained by 0.65 included in the medium category and contributed $24.22 \%$. The experimental class learning motivation result of $85.6 \%$ is classified as very high, and the control class result of $79.5 \%$ is classified as high.
\end{abstract}

Keywords: Creative Problem Solving Model; Accompanied by Student Worksheet; Environmental Pollution; Learning Outcomes; Learning Motivation

\section{Pendahuluan}

Pembelajaran dikelas melibatkan siswa sebagai pihak yang diajar dan guru sebagai pengajar sehingga tercipta interaksi antara keduanya (Sardiman, 2016). Tujuan pembelajaran akan terlaksana dengan baik jika perangkat pembelajaran telah sesuai dengan kondisi lingkungan

Aryanto, Universitas Tanjungpura Pontianak

Aryantoaryo6@gmail.com

Laili Fitri Yeni, Universitas Tanjungpura Pontianak

lailifitri74@gmail.com

Reni Marlina, Universitas Tanjungpura Pontianak reni.marlina@fkip.untan.ac.id 
yang diajar (Daryanto, 2013). Tujuan pembelajaran memiliki nilai yang sangat penting di dalam pengajaran (Hamalik, 2013). Ketika merumuskan tujuan pembelajaran guru dapat membuat behavior yang ingin diwujudkan, perilaku tersebut diharapkan dapat diterapkan oleh siswa (Dimyati dan Mudjiono, 2010). Rumusan tujuan belajar memuat perubahan tingkah laku yang diharapkan akan terwujud jika pembelajaran telah dirancang sebaik mungkin (Uno dan Nurdin, 2015).

Dalam proses interaksi antara siswa dan guru supaya berjalan dengan baik maka salah satunya dibutuhkan peranan guru dalam memilih model pembelajaran. Model pembelajaran berperan penting di kelas untuk mengarahkan guru dan merancang konsep informasiinformasi intruksional (Huda, 2015). Untuk mencapai tujuan pendidikan seorang guru dapat memilih model pembelajaran yang tepat dan efektif untuk dapat diterapkan di kelas (Uno dan Nurdin,2015). Model pembelajaran yang dipilih hendaknya menyesuaikan dengan materi pembelajaran sehingga model pembelajaran yang digunakan dapat diterapkan dengan baik pada materi pembelajaran tersebut.

Ilmu Pengetahuan Alam adalah materi pembelajaran yang erat kaitannya dengan alam secara sistematis. Ilmu Pengetahuan Alam mempelajari tentang gejala-gejala alam secara ilmiah yang dihasilkan berupa konsep, prinsip dan teori (Trianto, 2011). Melalui Ilmu Pengetahuan Alam kita dapat memecahkan masalah-masalah lingkungan hidup melalui proses identifikasi secara ilmiah (Takari, 2010). Salah satu pembelajaran IPA kelas VII SMP adalah materi pencemaran lingkungan, materi pencemaran lingkungan membahas mengenai pencemaran udara, pencemaran air, dan pencemaran tanah serta dampak pencemarannya bagi ekosistem.

Berdasarkan hasil wawancara dengan guru IPA di kelas VII SMPN 2 Pontianak, diperoleh informasi bahwa penyampaian materi pencemaran lingkungan menggunakan metode ceramah disertai diskusi. Untuk kesulitan belajar yang dialami pada materi pencemaran lingkungan ini adalah guru sulit untuk mengajak siswa untuk aktif berpikir, salah satu cara yang dilakukan guru adalah mengajak siswa untuk mengeluarkan ide-ide kreatifnya untuk mengatasi masalah pencemaran lingkungan namun kebanyakan siswa masih kurang aktif berpikir dalam proses pembelajaran dan cenderung pasif. Kesulitan belajar yang dialami siswa ini dapat mempengaruhi hasil belajar siswa dan menghambat terlaksananya tujuan pembelajaran.

Rendahnya hasil belajar dikarenakan pemahaman konsep siswa yang masih rendah terhadap materi pencemaran lingkungan. Hal ini karena siswa cenderung menghafal tanpa memahami materi. Dengan menghafal siswa meniru kalimat jawaban secara utuh berdasarkan sumber bacaan yang dibacanya, hal tersebut jika tidak diringi dengan memahami konsep dari suatu materi tersebut tentu materi tersebut akan mudah dilupakan. Kemudian motivasi siswa dianggap sebagai salah satu unsur yang dapat mempengaruhi hasil belajar. Meningkatnya prestasi belajar siswa pada mata pelajaran tertentu dapat dipengaruhi oleh faktor motivasi. Motivasi berasal dari dalam dan luar diri siswa yang berpengaruh terhadap perubahan tingkat laku (Uno, 2016). Yang dimaksud motivasi intrinsik adalah motif yang aktif berasal dari dalam sedangkan motivasi ekstrinsik motif yang aktif yang dipengaruhi dari luar (Sardiman, 2016). Dengan motivasi dapat mendorong timbulnya suatu perbuatan dengan cara tertentu sesuai dengan tujuan awal rencana yang diinginkan (Kompri, 2015). Belajar tanpa adanya motivasi akan mempersulit siswa sehingga mempengaruhi tingkat keberhasilan atau kegagalan belajar (Sani, 2016). Besar kecilnya motivasi akan menentukan cepat atau lambatnya suatu pekerjaan 
(Hamalik, 2013). Siswa yang bermotivasi tinggi dalam belajar memungkinkan akan memperoleh hasil belajar yang tinggi pula (Nashar, 2004).

Materi pencemaran lingkungan merupakan materi yang membahas mengenai permasalahan yang ada di lingkungan dan dekat dengan kehidupan sehari-hari oleh karena itu untuk memudahkan siswa dalam memahami konsep tersebut adalah dengan cara menerapkan suatu model pembelajaran yang berkaitan dengan pemecahan masalah. Terkait dengan implementasi kurikulum 2013 saat ini, yang menekankan keaktifan siswa dimana siswa dituntut untuk bisa menguasai materi secara mandiri dengan kreativitas yang ada dalam setiap individu masing-masing untuk memahami konsep-konsep materi yang harus dikuasai. Dalam pendidikan, kreativitas merupakan salah satu aspek penting. Kreativitas adalah kemampuan memecah masalah melalui pemberian solusi baru, asli, imajinatif serta penyelesaian masalah yang bersifat filosofis, estetis, maupun lainnya (Yahya, 2013). Untuk mendukung proses pembelajaran tersebut maka model pembelajaran yang berbasis pada pemecahan masalah akan sangat membantu dalam kegiatan pembelajaran. Salah satu model pembelajaran yang dapat diterapkan yaitu model Creative Problem Solving. Model Creative Problem Solving dapat memberikan solusi bagi siswa dalam menyelesaikan masalah secara kreatif yang erat kaitannya dalam kehidupan sehari-hari (Winarni, 2012). Model Creative Problem Solving dapat menguatkan keterampilan siswa dalam memecahkan masalah Ziqri dan Supriyanto, 2014). Penyelesaian masalah harus dilakukan dengan menerapkan prosedur yang tepat dalam menyelesaikan masalah (Sani, 2019). Keunggulan model Creative Problem Solving dapat membuat siswa memahami konsep-konsep dengan cara menyelesaikan masalah dan membuat siswa aktif (Pratiwi, Lia dan Agus, 2013). Melalui model Creative Problem Solving siswa akan diberikan beberapa masalah terkait materi pencemaran lingkungan kemudian siswa akan berpikir secara kreatif untuk menyelesaikan masalah tersebut.

Penggunaan model Creative Problem Solving dapat didukung dengan penggunaan bahan ajar. Bahan ajar yang dipilih dalam penelitian ini adalah lembar kerja siswa. Trianto (2010) menyatakan, "Lembar Kerja Siswa (LKS) memuat sekumpulan kegiatan mendasar yang harus dilakukan oleh siswa untuk memaksimalkan pemahaman dalam upaya pembentukan kemampuan dasar sesuai indikator pencapaian yang ditempuh". Dalam LKS siswa dapat menemukan arahan yang terstruktur untuk memahami materi yang diberikan (Prastowo, 2013). Penggunaan Lembar Kerja Siswa (LKS) diharapkan dapat membantu siswa untuk menerapkan dan mengintegrasikan konsep-konsep didalam materi pencemaran lingkungan yang terdiri dari beberapa sub materi meliputi definisi pencemaran lingkungan, pencemaran air, pencemaran udara, pencemaran tanah dan dampak pencemaran bagi ekosistem sehingga siswa dapat memahami materi tersebut sehingga diharapkan dapat mengatasi hasil belajar siswa yang rendah.

Melalui uraian mengenai model CPS dan LKS diatas peneliti berharap dapat membantu siswa meningkatkan hasil belajar dan motivasi belajar siswa. Tamrin (2012) dalam penelitiannya materi Limit Fungsi Aljabar telah membuktikan bahwa model Creative Problem Solving mampu meningkatkan hasil belajar siswa. Selain itu Putri, Syakbaniah dan Ratnawulan, (2015) dalam penelitiannya pada materi Bunyi, Cahaya dan Alat Optik mengenai pengaruh penerapan LKS berbasis Creative Problem Solving pada kelas eksperimen ranah kognitif 77,5 dan 
kelas kontrol 72,27. Mita (2009) dalam penelitiannya mengenai keefektifan model Creative Problem Solving pada materi Bangun Ruang Sisi Datar menunjukkan bahwa motivasi belajar siswa pada kelas eksperimen lebih tinggi dibandingkan dengan kelas kontrol. Berdasarkan uraian tersebut peneliti ingin melakukan penelitian untuk melihat efektivitas model Creative Problem Solving.

\section{Metode}

Penelitian ini menggunakan metode eksperimen dengan Nonequivalent Control Group Design. Populasi dalam penelitian ini adalah siswa kelas VII SMPN 2 Pontianak tahun pelajaran 2016/2017 dimana terdapat 7 kelas meliputi VIIA, VIIB, VIIC, VIID, VIIE, VIIF dan VIIG. Sampel dipilih dengan teknik intact group yaitu berdasarkan kelompok (Sutrisno, 2010). Berdasarkan hasil pre-test diambil sampel dengan mempertimbangkan nilai standar deviasi. Kemudian menentukan mana yang digunakan sebagai kelas eksperimen dan kelas kontrol dengan cara pengundian. Menurut Hadi (2015) cara ini dilakukan sebagaimana kita mengadakan undian. Kelas yang digunakan sebagai kelas eksperimen yaitu kelas VII D dan kelas kontrol yaitu kelas VII G.

Instrumen yang digunakan berupa tes dan angket motivasi belajar siswa. Jenis tes yang digunakan adalah pilihan ganda berjumlah 20 soal yang telah diuji validitas dan reabilitasnya. Pengolahan data angket menggunakan skala likert Riduwan (2014). Instrumen angket motivasi belajar dibuat dalam bentuk pernyataan positif dan negatif yang diisi oleh siswa. Penelitian ini menggunakan skala likert dengan menyajikan 12 pernyataan dengan 6 indikator motivasi belajar siswa yang terdiri dari enam pernyataan bersifat positif dan enam pernyataan bersifat negatif dengan 4 pilihan kategori untuk mengukur motivasi belajar siswa.

\section{Hasil dan Pembahasan}

Penelitian ini dilakukan pada kelas VII SMPN 2 Pontianak dengan tujuan untuk mengetahui efektivitas model Creative Problem Solving disertai LKS dengan melihat hasil belajar siswa pada materi pencemaran lingkungan. Penelitian ini dilaksanakan sebanyak tiga kali pertemuan untuk masing-masing kelas. Adapun kelas eksperimen yaitu kelas VII D dan kelas kontrol yaitu kelas VII G. Hasil belajar siswa pada kelas VII D dan kelas VII G dapat dilihat pada Tabel 1.

Tabel 1. Data Hasil Pre-test dan Post-test Siswa pada Materi Pencemaran Lingkungan

\begin{tabular}{ccccccc}
\hline & \multicolumn{3}{c}{ Kelas Eksperimen } & \multicolumn{3}{c}{ Kelas Kontrol } \\
\cline { 2 - 7 } Skor & $\overline{\boldsymbol{x}}$ & SD & $\begin{array}{c}\text { Ketuntasan } \\
\mathbf{( \% )}\end{array}$ & $\overline{\boldsymbol{x}}$ & SD & $\begin{array}{c}\text { Ketuntasan } \\
\mathbf{( \% )}\end{array}$ \\
\hline Pre-test & 12,61 & 1,64 & 13,89 & 13,23 & 1,61 & 25,71 \\
\hline Post-test & 17,89 & 1,37 & 100 & 16,94 & 1,45 & 100 \\
\hline
\end{tabular}

Data hasil pre-test siswa yaitu berupa skor dilakukan uji normalitas. Uji normalitas kelas eksperimen yaitu $(7,21<7,81)$ berdistribusi normal sedangkan uji normalitas kelas kontrol diperoleh yaitu $(9,37>7,81)$ tidak berdistribusi normal. Analisis data dilanjutkan dengan uji $U$ Mann Whitney yaitu $-1,96<0,73<1,96$. Hasilnya kedua kelas memiliki kemampuan awal yang 
sama. Data hasil post-test siswa yaitu berupa skor dilakukan uji normalitas. Uji normalitas kelas eksperimen yaitu $(8,07>7,81)$ tidak berdistribusi normal sedangkan uji normalitas kelas kontrol diperoleh yaitu $(2,72<7,81)$ berdistribusi normal. Analisis data dilanjutkan dengan uji U Mann Whitney yaitu 5,33 > 1,96. Hasilnya kedua kelas memiliki perbedaan hasil belajar.

Tabel 1 menunjukkan hasil belajar siswa pada materi pencemaran lingkungan. Hasil belajar jika dilihat pada tabel kedua kelas mengalami peningkatan pada saat setelah diberi perlakuan yang dapat dilihat dari skor post-test. Namun nilai post-test pada kelas eksperimen lebih tinggi dengan nilai 17, 89 sedangkan kelas kontrol 16, 94. Perbedaan hasil belajar juga dapat dilihat pada Gambar 1.

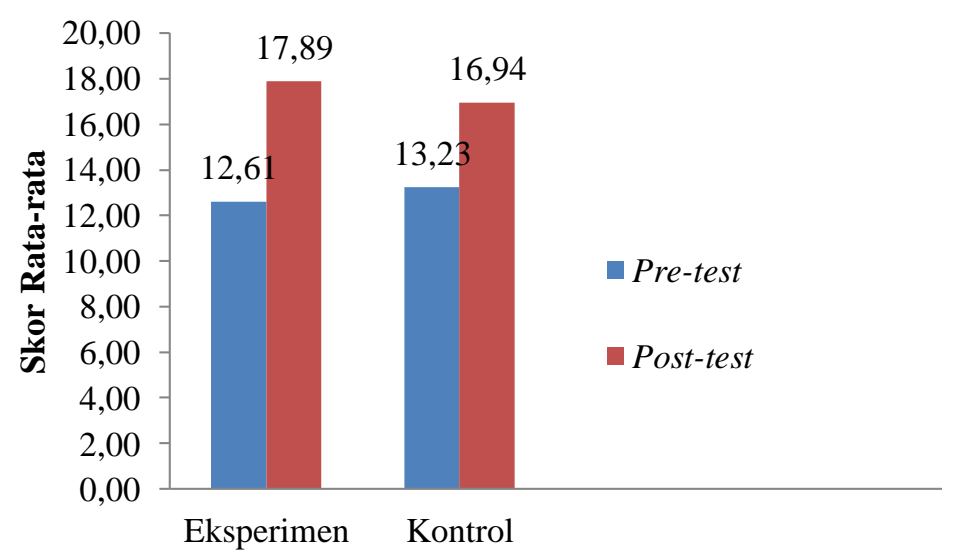

\section{Gambar 1. Rata-rata Skor Pre-test dan Post-test Siswa}

Berdasarkan Gambar 1 memperlihatkan peningkatan hasil belajar pada kelas eksperimen menunjukkan bahwa perlakuan pembelajaran menggunakan model Creative Problem Solving disertai LKS memberikan efek terhadap hasil belajar siswa. Berdasarkan tingginya hasil post-test yang diperoleh kelas eksperimen, tidak terlepas dari penerapan model Creative Problem Solving pada saat pembelajaran. Model Creative Problem Solving dapat memberikan solusi bagi siswa dalam menyelesaikan masalah secara kreatif yang erat kaitannya dalam kehidupan sehari-hari (Winarni, 2012). Model CPS memberikan kesempatan kepada siswa untuk memahami konsepkonsep dengan cara menyelesaikan suatu permasalahan. Pembelajaran di kelas kontrol yaitu ceramah disertai diskusi dirasa kurang efektif karena hanya beberapa siswa dari setiap kelompok yang aktif pada saat diskusi berlangsung dan siswa kurang bersemangat. Namun guru tetap berperan untuk selalu membimbing siswa agar semangat dan aktif terhadap proses pembelajaran yang berlangsung.

Proses belajar mengajar menghasilkan hasil belajar sejalan dengan tujuan yang ingin dicapai (Purwanto, 2011). Di dalam pendidikan tidak terlepas dari sebuah penilaian, melalui hal tersebut didapat hasil belajar yang terukur yang menunjukkan apakah proses pembelajaran sudah terlaksana dengan efektif. Keberhasilan tersebut dapat diketahui dari ketuntasan belajar siswa dalam mengerjakan soal yang diberikan sesuai dengan setiap tujuan pembelajaran. Presentase ketuntasan hasil belajar siswa pertujuan pembelajaran bisa dilihat pada Tabel 2 . 
Tabel 2. Persentase Ketuntasan Hasil Belajar Siswa

\begin{tabular}{|c|c|c|c|c|c|}
\hline \multirow{2}{*}{ No. } & \multirow{2}{*}{ Tujuan Pembelajaran } & \multicolumn{2}{|c|}{$\begin{array}{c}\text { Rata-rata Persentase } \\
\text { Jawaban Benar Per Soal }\end{array}$} & \multicolumn{2}{|c|}{$\begin{array}{c}\text { Rata-rata Persentase } \\
\text { Jawaban Benar Per Tujuan } \\
\text { Pembelajaran }\end{array}$} \\
\hline & & $\begin{array}{c}\text { Eksperimen } \\
(\%)\end{array}$ & $\begin{array}{c}\text { Kontrol } \\
(\%)\end{array}$ & $\begin{array}{c}\text { Eksperimen } \\
(\%)\end{array}$ & $\begin{array}{c}\text { Kontrol } \\
(\%)\end{array}$ \\
\hline \multirow{3}{*}{1.} & \multirow{3}{*}{$\begin{array}{l}\text { Siswa dapat menjelaskan } \\
\text { pengertian pencemaran } \\
\text { lingkungan }\end{array}$} & 86,11 & 82,86 & \multirow{3}{*}{84,26} & \multirow{3}{*}{86,67} \\
\hline & & 94,44 & 85,71 & & \\
\hline & & 72,22 & 91,43 & & \\
\hline \multirow{3}{*}{2.} & \multirow{3}{*}{$\begin{array}{l}\text { Siswa dapat menjelaskan } \\
\text { pengertian pencemaran air }\end{array}$} & 91,67 & 48,57 & \multirow{3}{*}{94,44} & \multirow{3}{*}{75,24} \\
\hline & & 97,22 & 94,29 & & \\
\hline & & 94,44 & 82,86 & & \\
\hline \multirow{2}{*}{3.} & \multirow{2}{*}{$\begin{array}{l}\text { Siswa dapat menjelaskan } \\
\text { dampak pencemaran air beserta } \\
\text { pemecahan masalahnya }\end{array}$} & 94,44 & 94,29 & \multirow{2}{*}{84,72} & \multirow{2}{*}{74,29} \\
\hline & & 75,00 & 54,29 & & \\
\hline \multirow{2}{*}{4.} & \multirow{2}{*}{$\begin{array}{l}\text { Siswa dapat menjelaskan } \\
\text { pengertian pencemaran udara }\end{array}$} & 97,22 & 85,71 & \multirow{2}{*}{87,5} & \multirow{2}{*}{87,14} \\
\hline & & 77,78 & 88,57 & & \\
\hline \multirow{3}{*}{5.} & \multirow{3}{*}{$\begin{array}{l}\text { Siswa dapat menjelaskan } \\
\text { dampak pencemaran udara } \\
\text { beserta pemecahan masalahnya }\end{array}$} & 100,00 & 91,43 & \multirow{3}{*}{91,67} & \multirow{3}{*}{85,71} \\
\hline & & 94,44 & 80,00 & & \\
\hline & & 80,56 & 85,71 & & \\
\hline 6. & $\begin{array}{l}\text { Siswa dapat menjelaskan } \\
\text { pengertian pencemaran tanah }\end{array}$ & 88,89 & 94,29 & 88,89 & 94,29 \\
\hline \multirow{4}{*}{7.} & \multirow{4}{*}{$\begin{array}{l}\text { Siswa dapat menjelaskan } \\
\text { dampak pencemaran tanah } \\
\text { beserta pemecahan masalahnya. }\end{array}$} & 77,78 & 82,86 & \multirow{4}{*}{86,11} & \multirow{4}{*}{87,15} \\
\hline & & 97,22 & 88,57 & & \\
\hline & & 88,89 & 82,86 & & \\
\hline & & 80,56 & 94,29 & & \\
\hline \multirow{2}{*}{8.} & \multirow{2}{*}{$\begin{array}{l}\text { Siswa dapat membedakan jenis- } \\
\text { jenis sampah yang dapat di daur } \\
\text { ulang menjadi kompos }\end{array}$} & 97,22 & 82,86 & \multirow{2}{*}{97,22} & \multirow{2}{*}{80} \\
\hline & & 97,22 & 77,14 & & \\
\hline & Rata-rata & & & 89,35 & 83,81 \\
\hline
\end{tabular}


Berdasarkan Tabel 2 menunjukkan kemampuan menjawab soal kelas eksperimen memperoleh presentase 89,35\% dan kelas kontrol memperoleh persentase sebesar 83,81\%. Dari data tersebut dapat disimpulkan bahwa pada kelas eksperimen memiliki rata-rata yang lebih tinggi dalam menjawab benar soal post-test pada setiap tujuan pembelajaran. Penggunaan model Creative Problem Solving disertai LKS pada penyampaian materi ini lebih memusatkan pada keterampilan dalam pemecahan masalah, siswa pada tahapan model Creative Problem Solving khususnya pada tahapan memunculkan gagasan dan mengembangkan solusi melatih siswa melalui diskusi kelompok untuk dapat mengumpulkan informasi dan mengeluarkan ideide untuk mengatasi dampak dari masalah pencemaran. Hal ini sejalan dengan pendapat Winarni (2012) yang menjelaskan bahwa model Creative Problem Solving (CPS) adalah suatu model yang dapat menciptakan pembelajaran yang dapat merangsang siswa menyelesaikan masalah secara kreatif sehingga dapat digunakan dalam kehidupan sehari-hari. Berdasarkan analisis perhitungan diperoleh harga Effect Size senilai 0,65 dengan kategori sedang. Melihat tabel kurva normal dari tabel $\mathrm{O}-\mathrm{Z}$, maka menunjukkan pembelajaran dengan model Creative Problem Solving disertai LKS berpengaruh senilai 24,22\% terhadap hasil belajar siswa pada materi pencemaran lingkungan kelas VII SMPN 2 Pontianak.

Motivasi yang dimaksud dalam penelitian ini adalah motivasi yang timbul akibat karena indikator motivasi intrinsik dan ekstrinsik (Uno, 2016). Angket motivasi belajar meliputi enam indikator yaitu adanya dorongan untuk belajar materi pencemaran lingkungan, adanya kemauan mendapatkan hasil belajar yang memuaskan, adanya impian akan cita-cita, adanya keinginan siswa untuk memperoleh penghargaan dalam belajar, adanya kegiatan yang menarik dalam belajar dan adanya suasana belajar yang kondusif. Enam indikator tersebut dibagi menjadi enam pernyataan positif meliputi no 1, 3, 5, 7, 9, 11 dan enam pernyataan negatif meliputi no 2, 4, 6, 8, 10, 12. Perhitungan hasil angket motivasi belajar siswa pada kelas eksperimen yaitu $85,6 \%$ termasuk kategori sangat kuat, sedangkan pada pada kelas kontrol yaitu $79,5 \%$ termasuk kategori kuat.

Motivasi yang diukur meliputi motivasi intrinsik dan motivasi ekstrinsik. Besarnya motivasi intrinsik dan ekstrinsik siswa secara keseluruhan dapat dilihat pada Tabel 3.

Tabel 3. Hasil Rata-rata \% Persetujuan dan Ketidaksetujuan Tiap Jenis Motivasi

\begin{tabular}{ccc}
\hline \multirow{2}{*}{ Jenis Motivasi } & \multicolumn{3}{c}{ Rata-rata \% } \\
\cline { 2 - 3 } & Kelas Eksperimen & Kelas Kontrol \\
\hline Intrinsik & 88,2 & 80,7 \\
\hline Ekstrinsik & 83 & 78,3 \\
\hline Total & 85,6 & 79,5 \\
\hline
\end{tabular}

Berdasarkan Tabel 3 hasil perhitungan motivasi intrinsik pada kelas eksperimen memiliki nilai lebih tinggi yaitu $(88,2)$ sedangkan pada kelas kontrol yaitu $(80,7)$. Untuk motivasi entrinsik juga demikian pada kelas eksperimen lebih tinggi yaitu (83) sedangkan kelas kontrol $(78,3)$. Jika dilihat dari total keseluruhan motivasi intrinsik memiliki nilai yang lebih tinggi dibandingkan dengan nilai motivasi ekstrinsik. Hal tersebut bisa terjadi karena pada dasarnya sejak awal motivasi intrinsik sudah ada dalam diri setiap siswa, sedangkan motivasi ekstrinsik berasal dari dorongan luar yang juga diperlukan dalam kegiatan pembelajaran untuk 
dapat menarik minat belajar siswa. Menurut Sardiman (2016) motivasi intrinsik ada didalam diri setiap individu yang mendorong untuk melakukan sesuatu sedangkan motivasi ekstrinsik ialah motif yang berfungsinya karena adanya rangsangan dari luar. Kedua jenis motivasi tersebut sama-sama penting dalam kegiatan belajar, oleh karena itu motivasi perlu dibangkitkan oleh guru sehingga para siswa memiliki keinginan belajar yang besar dan berpengaruh pada hasil belajar yang baik. Perbedaan skor total motivasi belajar siswa pada kelas eksperimen dan kelas kontrol dapat dilihat pada Gambar 2 di bawah ini.

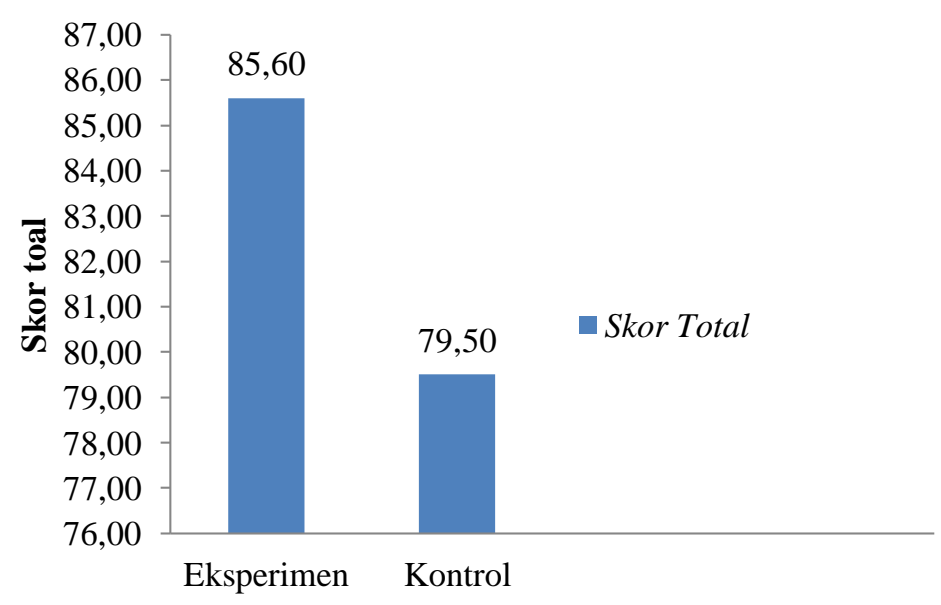

\section{Gambar 2. Skor Total Motivasi Belajar Siswa}

Dari Gambar 2 terlihat tingkat persetujuan motivasi belajar siswa setelah diberi perlakuan dengan model Creative Problem Solving disertai LKS yaitu sebesar 85,6\% yang termasuk dalam kategori sangat kuat sedangkan yang diajar dengan pembelajaran konvensional yaitu sebesar $79,5 \%$ yang termasuk dalam kategori kuat. Hamalik (2013) menjelaskan bahwa motivasi yang tinggi berkaitan dengan kreativitas siswa. Kegiatan pembelajaran yang kreatif dan menarik tidak terlepas dari penggunaan model pembelajaran yang tepat. Model CPS menyediakan konsep materi yang merangsang kreatifitas siswa dalam memecahkan masalah (Huda, 2015).

\section{Simpulan}

Berdasarkan hasil penelitian disimpulkan bahwa hasil belajar siswa pada materi Pencemaran Lingkungan yang diajarkan dengan model Creative Problem Solving disertai LKS yaitu 17,89 sedangkan metode konvensional yaitu 16,94. Hasil perhitungan Effect Size diperoleh nilai 0,65 termasuk dalam kategori sedang dengan luas daerah sebesar 24,22. Hal ini berarti Model Creative Problem Solving disertai LKS memberikan kontribusi sebesar $24,22 \%$ terhadap hasil belajar siswa pada materi pencemaran lingkungan kelas VII SMPN 2 Pontianak. Untuk perhitungan angket motivasi belajar siswa diperoleh model Creative Problem Solving disertai LKS yaitu sebesar 85,6\% termasuk dalam kategori sangat kuat sedangkan yang diajar dengan metode konvensional sebesar yaitu 79,5\% termasuk dalam kategori kuat. 


\section{Daftar Rujukan}

Daryanto. (2013). Inovasi Pembelajaran Efektif. Bandung: Yrama Widya.

Dimyati \& Mudjiono. (2010). Belajar dan Pembelajaran. Bandung: Rineka Cipta.

Hadi, S. (2015). Metodologi Riset. Yogyakarta: Pustaka Pelajar.

Hamalik, O. (2013). Proses Belajar Mengajar. Jakarta: Bumi Aksara.

Huda, M. (2015). Model-Model Pengajaran dan Pembelajaran: Isu-Isu Metodis dan Paradigmatis. Yogyakarta: Pustaka Pelajar.

Kompri. 2016. Motivasi Pembelajaran Perspektif Guru dan Siswa. Bandung: PT Remaja Rosdakarya.

Mita, R. 2009. Keefektifan Model Pembelajaran Creative Problem Solving (CPS) terhadap Motivasi dan Hasil Belajar Siswa Kelas VIII Semester II SMP N 1 Lebaksiu pada Materi Bangun Ruang Sisi Datar. Skripsi, FMIPA, Jurusan Matematika, Universitas Negeri Semarang.

Nashar. (2004). Peranan Motivasi dan Kemampuan Awal dalam Kegiaan Pembelajaran. Jakarta: Delia Press.

Prastowo, A. (2013). Bahan Ajar Tematik: Tinjauan Teoritis \& Praktik. Yogyakarta: Kencana Prenada Group.

Pratiwi, W.T., Lia Y. \& Agus, S. 2013. Pengaruh Penerapan Creative Problem Solving (CPS) terhadap Kemampuan Berpikir Kritis Siswa pada Mata Pelajaran Fisika Kelas XI IPA MAN 3 Malang. Skripsi, FMIPA, Jurusan Fisika, Universitas Negeri Malang.

Purwanto. (2011). Evaluasi Hasil Belajar. Yogyakarta: Pustaka Belajar.

Putri, R.C., Syakbaniah \& Ratnawulan. 2015. Pengaruh Penerapan LKS Berbasis Model Creative Problem Solving pada Materi Bunyi, Cahaya dan Alat Optik terhadap Hasil Belajara IPA Siswa Kelas VIII SMPN 3 Padang. Jurnal Pillar of Physics Education, 6, 9-16.

Riduwan. (2014). Metode dan Teknik Menyusun Tesis. Bandung: Alfabeta.

Sani, R.A. (2016). Inovasi Pembelajaran. Jakarta: Bumi Aksara.

Sani, R.A. (2019). Pembelajaran Berbasis Hots (Higher Order Thinking Skills). Tangerang: Tira Smart.

Sardiman, A.M. (2016). Interaksi Motivasi Belajar Mengajar. Jakarta: Rajawali Press.

Sutrisno, L. (2010). Effect Size. (Online). (http://www.scribd.com/doc/131910444/MetaAnalisis-Effect-Size\#scribd. 
Takari, E. (2010). Model Pembelajaran Kooperatif IPA 2. Jakarta: Ganesindo.

Tamrin, M.B. 2012. Efektivitas Model Pembelajaran Creative Problem Solving (CPS) dalam Meningkatkan Hasil Belajar Siswa pada Materi Limit Fungsi Aljabar (Penelitian pada Siswa Kelas XI - IPA SMA Negeri 4 Kota Ternate). Jurnal Matematika dan Pendidikan Matematika, 1(2), 31-42.

Trianto. (2010). Model Pembelajaran Terpadu dalam Teori dan Praktek. Jakarta: Prestasi Pustaka.

Trianto. (2011). Model Pembelajaran Terpadu Konsep Strategi dan Implementasinya dalam Kurikulum Tingkat Satuan Pendidikan. Jakarta: Bumi Aksara.

Uno, H.B. \& Nurdin, M. (2015). Belajar dengan Pendekatan PAIKEM: Pembelajaran Aktif, Inovatif, Lingkungan, Kreatif, Efektif, Menarik. Jakarta: Bumi Aksara.

Uno, H.B. (2016). Teori Motivasi dan Pengukurannya: Analisis di Bidang Pendidikan. Jakarta: Bumi Aksara.

Winarni, E.W. 2012. Inovasi dalam pembelajaran IPA. Bengkulu: FKIP Universitas Bengkulu.

Yahya, M. 2013. Pengembangan Kreativitas Siswa dalam Proses Pembelajaran di Madrasah Aliyah Ma'arif Ambulu Jember. Jurnal Fenomena, 5(1).

Ziqri, I.M. \& Supriyanto. (2014). Efektivitas Model Pembelajaran Creative Problem Solving pada Materi Sistem Pernapasan di SMAN 1 Jatibarang Brebes. Unnes Journal of Biology Education, 3(3), 254-260. 